By JAMES L. CLIFFORD

\title{
Reading and the College Library
}

$I^{\mathrm{F}}$ COLLEGE LIBRARIANS sometimes appear harassed and perplexed, the recent rapid rise in enrollments is only one cause of worry. Equally important, though perhaps less publicized, is the fact that within the last half century there has occurred a major shift in our reading habits, and, as a result, libraries are now called upon to provide services which used to be found elsewhere.

Let me illustrate by some personal recollections. As I grew up, the center of my education was in the home. My parents, for whom this beautiful library is named, ${ }^{1}$ were avid readers. Indeed, no two people ever loved books more. What stands out clearest in all my childhood memories is books - walls lined with books-books on the tables-books stored in boxes and cases in the attic. And they were not on the shelves merely for decoration; they were being read.

Mother was an enthusiastic reader of history, biography, and poetry. From the time that she left Wellesley College after only one year, she started the practice of buying large quantities of books. Heavy packages would regularly arrive from a well-known Boston bookseller, filled with sets of the classics and the historians - collected works of the major figures of literature. More and more bookcases had to be purchased, and soon they lined every available wall in the large middle-western family home.

For her the love of books remained a

1 This article is part of an address given at the dedication of the Clifford Memorial Library of Evans ville College, Evansville, Indiana, on March 19, 1957

Dr. Clifford is professor of English, Columbia University, and the author of the recently published Young Sam Johnson. lifetime obsession. Even when her eyesight finally failed, she kept up with the best literature through talking records for the blind. Scornful of the soap operas and melodramas which made up the usual daytime radio programs, she demanded, even in her eighties, solid intellectual stimulus, and kept the mailman busy bringing large packages of books. In her last year, when almost eightyfive, she insisted on listening to a new version of one of the old Greek classics, and passing on its story to her grandchildren.

Father, too, was a buyer of books, with a wide variety of interests - chiefly science, theology, and politics. His collection of books on astronomy was outstanding. He tried to keep up on every subject, and was always complaining about lack of time to range as far as he would have liked.

To be sure, neither Mother nor Father was a collector in the strict sense of the word. They had no interest whatsoever in first editions or rare volumes. They did not delight in beautiful bindings or in de luxe publications. They had no bibliographical tastes, and little scholarly discrimination in the choice of texts. Father's attitude was that the more books he could buy for the money he had to spend the better. It was what was inside the books that counted.

Nor were my parents the kind of possessive book lovers who insist on reading only what they have in their own collections. There were constant visits to the library-not a short trip by horse and carriage in those days-and the stacks of borrowed books on the living room table were continually changing. But basically it was the mass of books 
permanently on our own shelves which made up the core of our family life.

Both Father and Mother read aloud to us children from the time we could understand, and there was never any condescending to childish tastes. Father was a slow reader, who grappled with every word, and Mother one of the most rapid I have ever known. When reading merely for her own pleasure she would dash through a volume with amazing speed. When reading out loud she would push ahead for hours, never apparently tired or bored. Between the two, my brother and I were exposed to a neverending succession of classics - novels, biography, history - all of Scott, Dickens, Thackeray, together with lesser writers whom not many people today would even remember. On our shelves, I recollect, there was a twenty-six volume set of the complete works of Bulwer-Lytton, which Father methodically read to us from beginning to end. To this day I have a sentimental and nostalgic feeling about that minor Victorian novelist, not for the well-known Last Days of Pompeii, which everybody read, but for other long-forgotten novels like What Will He Do With It? and Paul Clifford.

On Sunday afternoons there were more serious works. Mother took us through the long histories by Parkman and Prescott, and the whole of Motley's Rise of the Dutch Republic. Father introduced us to some of the eighteenthcentury classics: selected passages from the letters of Lord Chesterfield, to teach us good manners (and I have heartily disliked Chesterfield ever since), and Adam Smith's Wealth of Nations. The only time, I remember, that we successfully rebelled was over Bishop Joseph Butler's Analogy of Religion, Natural and Revealed, to the Constitution and Course of Nature, which even Father at last found too heavy going.

It was my parents' theory that children would benefit from hearing serious books read aloud, even though the level was pitched higher than their immediate comprehension. It was mental stretching which was important. If the main themes went over our heads, and if we played with tin soldiers while the reading was going on, they thought that the characters from the novels would make some impression, and the sound of the words, those long Victorian cadences, would become part of our imaginative thinking.

I like to think that my parents' theory was correct - that my brother and I did get something real and lasting from those long hours of exposure to the classics. That it fostered a love of reading is undeniable. As I grew older, I developed the habit of browsing among those books that had been read to me years before. I can't say that I actually read them all again, but I kept going back to favorite passages and to beloved characters such as Dick Swiveller and the Marchioness in Dickens' Old Curiosity Shop, Mark Tapley in Martin Chuzzlewit, and Captain Cuttle in Dombey and Son. I doubt if I ever went all through that four-foot set of Bulwer-Lytton, but even there I devoured some of the novels over and over. Then there were favorite scenes from the past to be found in the many volumes on American history-exciting adventures of explorers, or accounts of scientific discovery. The books were facing me every day as I passed through the rooms and halls. It was easy to stop and pull out a volume, drop into an easy chair, and thumb through the pages. Along with the old favorites there were others which I had never heard of. The walls of books were an ever-present lure to further delights. So it was that I ranged about merely as the whim of the moment directed.

It was in this way, you may remember, that Samuel Johnson in the eighteenth century acquired most of the wide knowledge which fitted him to produce the first great dictionary of the English language. Since his father was a country bookseller, the boy had access to thou- 
sands of volumes as they passed through the shop. These he was able to sample, to dip into as he wished, to savor with happy excitement. He always felt that he had acquired more of value from such casual dipping than by any later imposed assignments. A boy's own discoveries, he said, make more impression than any forced-discipline. And I am sure that he was right.

But you will be eager to reply that the kind of large family library which I have been describing scarcely exists today. I will at once agree, and I am afraid that there are incontrovertible reasons why it will never come back. No matter how much we may deplore its passing, there are practical reasons that stand in the way of many parents' achieving the sort of bookish surroundings which my father and mother provided for their boys. Yet this is no reflection on the intelligence or tastes of the present generation. It is simply that conditions have radically changed. That fine books are more expensive is only one consideration. Most people today simply do not have the physical space to house thousands of volumes. People now want smaller houses which are easier to take care of. Few have the necessary help to keep long shelves of books dusted.

Changes of building methods and a new taste in interior decoration have combined to banish great family collections of books. Compare the kind of Victorian house that I was brought up in with a typical compact ranch house today. In the old homes there was always a large room set off as a library, and when its shelves were filled there were many dark halls and other rooms waiting to be filled. People liked cluttered rooms, and apparently the more bookcases and bric-a-brac the better. Besides, there was always a spacious attic to handle the overflow.

Whoever heard of a medium-priced modern house with a special room for a library? To be sure, there may be a com- bination library and rumpus room or combination television and book room with a few shelves for magazines and the most recent selections of the Book-ofthe-Month Club. But modern methods of construction, which now can employ wider windows and less wall space, leave little room for book shelves. I wonder how many people have thought about the effect of the increase of light in modern houses - with broad picture-windows or rows of dormers - on the reading habits of our children. With constantly shrinking wall space there are fewer places for books.

Modern taste in interior decoration is also partly responsible. Today we dislike clutter. Our aesthetic approach is becoming more severe, and we prefer plain walls and the opposition of masses of color. Dog-eared volumes or the variegated patterns produced by differing jacket designs tend to spoil the modern decorator's schemes. A friend recently told me of the remark of a well-known interior decorator who had been called in to advise about re-doing a living room. When the professional heard that space must be provided for shelves of books, he was horrified, and protested violently. "One of the few good things about Hitler," he growled, "was that he burned so many books."

I have friends-literate, bookish friends - who shudder every time they are lured into buying a new book, or have one given to them-wondering where they can put it on their meager shelves. Something will have to be thrown away to make the space for each new acquisition. In a small apartment or ranch-style house, with no attic, no wall space for bookcases, they simply cannot have the fun of book collecting that their parents had.

Now I should be sorry to sound like the proverbial discontented old timer, complaining that nothing is the way it was when I was young, that everything is going to the dogs, merely because peo- 
ple cannot now have large private libraries. I am well aware that not all families today have foregone culture, that there are other media for intellectual stimulation. I know you will say that we now see classics on television or at the movies. We can pick them up in paper-backs at the drug store, read them quickly, and throw them away. Indeed, you may claim that more people are actually being exposed to the great imaginative works of the past than in the days when a few privileged children could read them at home. And again I will agree. There is no doubt that television and the movies have greatly widened our base of culture. In total numbers the change has been remarkable, though I might add in an aside that the percentage figures showing how many people watch the classics on television are sometimes disillusioning. For example, four times as many people preferred to watch "I Love Lucy" than to switch to a spectacular production of Romeo and Juliet. Yet even if only 10 per cent of the viewers in the country can be lured into watching a classic, that means millions more than would ever read the book.

All this is good. Quantitatively, the effect has been outstanding. Yet I have some qualms as to the qualitative effect of all this democratization. In order to make certain of the appeal to a wide audience, it has been necessary to simplify everything. There is constant censorship so as to keep from offending this group or that. In the major mass media there is a continual effort to shield us from controversial issues. Moreover, there is always some cutting. Classics must be made easy for all kinds of viewers. Those in charge seem to think that if the ideas of the past are to be brought to millions of people who would never reach for a book, everything must be carefully adjusted to a teen-age level. No one must be bored by things he cannot understand. If there is to be any mental stretching, it must be done by very slow degrees.

Yet when everything is brought down to the teen-age level, when all abstruse and unusual words are eliminated from our reading, there is little development of the mind. I like to think that when I listened as a boy to four feet of the works of Bulwer-Lytton, with all his turgid style and pompous language, with all his formal approach and verbose descriptions, it was of more value to me than any number of modern abridg. ments or television presentations carefully adjusted to what would be considered my proper mental level.

Yet I can imagine many of you muttering: "What is all this leading to? Why all this tearing of hair over something which cannot be changed? Who today could ever find time to read through all those old, stuffy and tedious classics? The pace of modern life makes this impossible. And you have yourself already admitted that physical limitations of modern houses preclude the amassing of large family libraries. Life has changed, and we must do the best we can in the new frame of reference. What else can we do?"

The answer to the protest about time is easy. There is always time to do what one wants most. People find time for double features and for three-hour spectaculars. Something would have to be sacrificed, of course, but there is always time for serious reading if there is a genuine desire.

The answer to the other complaint brings me squarely to the door of the librarian. Now that so few of us have the opportunity to live with thousands of family books, the general library, public and college, must take the place of that beneficent and broadening atmosphere. For most young people today it will represent the one surviving mental challenge, the one last ditch stand of undigested knowledge. It is the one place where young men and women today may 
be exposed to the really hard books, to those that defy abridgment, to those that demand intense study and continual rereading - the kind of abstruse volumes that cannot be found in drugstores or distributed by book clubs.

The college library, in particular, need not be designed to pander to easy modern tastes, but to widen the frontiers of knowledge. It is a place where censorship and leveling can be resisted, where ideas can be valued not for their marketability but for their basic truth. It is the one place where best-sellers do not necessarily have the front shelves. And, incidentally, it is one place where one can get away from the telephone.

But if the college library is to become the center of a student's education, if it is to take the place of the vanishing home collections, it must offer much more than utilitarian services in preparing assignments. Of course, there should be expert help with course work. Assigned reading and research are basic in a college, I should almost say absolutely central to the whole process of learning. But they are not everything.

Another function of the library must be to provide intellectual breathing space. It is often more important for a student to broaden his whole outlook on life than to grind out routine work, and casual browsing may be as valuable as carefully planned reading.

Dr. Johnson, whom I mentioned earlier, used to say that he found great pleasure merely in looking at the backs of books on the shelves. On one memorable occasion, which Boswell described in his famous biography, Johnson went out to Twickenham, together with Boswell and Sir Joshua Reynolds, to dine with a minor writer of the day, Richard Owen Cambridge. In his own inimitable way Boswell tells what occurred when they arrived:

No sooner had we made our bow to Mr. Cambridge, in his library, than Johnson ran eagerly to one side of the room, intent on poring over the backs of the books. Sir Joshua observed (aside), "He runs to the books, as I do to the pictures. ..."

And when their host commented on the oddity, which he himself had, of delighting in merely looking at books on the shelves, Johnson wheeled about and answered:

Sir, the reason is very plain. Knowledge is of two kinds. We know a subject ourselves, or we know where we can find information upon it. When we inquire into any subject, the first thing we have to do is to know what books have treated of it. This leads us to look at catalogues, and at the backs of books in libraries.

Fanny Burney, too, tells how whenever Johnson came into a room he instantly pored over the lettering on each volume within his reach. Shelf by shelf he would curiously see what was there, and because of his nearsightedness he would move along with his eyelashes almost brushing the volumes.

I have sometimes wondered if there was not some kind of intellectual osmosis which occurs when one indulges in this kind of shelf reading. Merely looking at the titles is broadening, for in some mysterious manner something of the contents of the books appears to pass on to the viewer. Whether it be by association of ideas-from the title or the name of the author-or whether it be by some other process of assimilation-old memories are revived and new associations suggested.

Of course, the best kind of shelf reader is the "dipper." He is the one who lets his eye run down the stacks of books, and when a title strikes some chord of curiosity, pulls the volume off the shelf and carelessly thumbs through the pages. Not all books have to be completely digested. Some, says Bacon, need only be tasted. "Sir, do you read books through?" Johnson once exploded. And he was not 
only expressing impatience at the plodding scholar for whom reading was primarily a duty, but urging the delight of skimming through large tracts of knowledge with no intent to become an expert. Education, as he well knew, is much more than the acquiring of information. It is a way of life, a point of view. It is basically the nurturing of an intellectual curiosity which transcends the practical needs of the moment.

The moral of all this should by now be clear. College libraries of the future, if they are to take the place of the rapidly diminishing home collections, must concentrate on making shelf reading and browsing convenient and easy. This ob- viously means open shelves everywhere, with plenty of light and easy chairs. This may mean new experiments in arranging and cataloging the books. It may even be possible to discover new ways of tempting curious students into skimming through areas of knowledge far removed from their own special fields.

But here I rashly step outside the range of my own competence, for the practical means of achieving these utopian goals must be worked out by librarians themselves. One thing is certain: the challenge is there. Somehow young people must be brought to think of the library not merely as a service station, but as their intellectual home.

\section{Eastern Librarians' Conference}

The forty-third Annual Eastern College Librarians' Conference will be held this year at Columbia University in New York City on Saturday, November 30,1957 . The conference will be devoted to two current problems in academic libraries: The Evaluation of Academic Libraries and College Libraries and Expanding Enrollments. At the morning session Maurice Tauber, Melvil Dewey Professor of Library Service at Columbia University, will present a case study report of the recently concluded self-survey of the Columbia University Libraries. Morris Gelfand, librarian of Queens College, will discuss the practical techniques used in evaluating libraries by accrediting teams.

Millicent McIntosh, president of Barnard College, will begin the afternoon session with a discussion of "The Future of the American College." She will be followed by Wyman Parker, librarian of Wesleyan University, Middletown, Connecticut, who will speak on "College Library Standards and the Future." Wayne Yenawine, dean of the Syracuse University School of Library Science, will talk on "Trends in Education for Academic Librarianship."

The conference will be held in the Harkness Theater on the Columbia University campus. No advance registration is necessary. .Correspondence concerning the conference should be addressed to Russell Shank, Program Chairman, Eastern College Librarians Conference, Columbia University Libraries, New York 27, N. Y. 